\title{
A review on the purification and use of biogas in compression ignition engines
}

\author{
M. Feroskhan and Saleel Ismail* \\ School of Mechanical and Building Sciences, \\ VIT University Chennai, Chennai, Tamilnadu, India. \\ *E-mail: saleelismail@vit.ac.in
}

\begin{abstract}
Biogas is commonly produced during the decay of organic matter. It is a mixture of methane and some non-combustible gases such as $\mathrm{CO}_{2}$ and $\mathrm{H}_{2} \mathrm{~S}$. Its viability as a renewable alternative fuel for internal combustion engines can be enhanced by methane enrichment, i.e. removal of the non-combustible constituents. One of the common techniques for using biogas in a compression ignition (CI) engine is to mix it with air in the intake manifold, induct, and compress this mixture and ignite it by injecting a small quantity of diesel or bio-diesel, which is termed as the pilot fuel. This is known as the dual fuel mode. The pilot fuel is injected close to the end of the compression stroke as in a conventional CI engine and the injected fuel quantity depends on the operating condition. An alternative approach is the Homogeneous Charged Compression Ignition (HCCI) mode. Here, a homogeneous mixture of biogas and air is inducted and compressed by the piston until it auto-ignites. While this concept combines the benefits of spark ignition (SI) and CI engines, the onset of combustion cannot be controlled directly. A detailed review of recent research pertaining to biogas purification techniques and operation of CI engines with biogas in dual fuel and HCCI modes is presented in this paper. The effects of various operating parameters on engine performance and emissions, and comparison with conventional diesel fuelled CI engines are discussed. Biogas improves combustion efficiency, $\mathrm{NO}_{\mathrm{x}}$, and smoke emissions. However, it reduces brake thermal efficiency, volumetric efficiency, and increases HC and $\mathrm{CO}$ emissions. Biogas fuelling of $\mathrm{CI}$ engines is recommended for achieving high diesel substitution, especially under high torque operation.
\end{abstract}

Keywords: Biogas; CI engine; dual fuel; HCCI; methane enrichment

\section{INTRODUCTION}

The world's primary energy resources such as petroleum, natural gas, coal, and nuclear fuels are not renewable. Their rapid depletion, consequent rise in prices, increased global energy demand, and concern for environmental protection have escalated the quest for alternative, renewable sources of energy like solar energy, hydro energy, wind energy, and biofuels [1]. Furthermore, petroleum reserves are largely concentrated in a few regions of the world. Countries in other regions face severe crisis in bridging the gap between energy demand and fuel supply [2]. Fossil fuel combustion also results in air pollution, acid rain, and build-up of carbon dioxide, thus putting human beings and the environment at risk [3-7]. Among the alternatives to fossil fuels, biofuels such as biogas, alcohols, and biodiesels have received considerable attention due to their renewable nature and their inherent potential to bring down net $\mathrm{CO}_{2}$ emission [8-11]. 
Using biogas as a fuel addresses three major challenges; identifying a renewable source of energy, effective disposal of biological waste, and harnessing methane, a potent greenhouse gas emanating from decomposing biomass. Biogas offers several advantages over other fuels derived from biomass. It can be transported easily via pipelines or as a compressed gas in cylinders once the corrosive components, viz. $\mathrm{CO}_{2}$, $\mathrm{H}_{2} \mathrm{~S}$, and water vapour are removed [12]. Compared to solid fuels like coal, biogas burns faster and leaves no residue behind and is more environment-friendly. Biomass, which is the source of biogas, can ultimately be traced back to vegetation. These plants/trees absorb $\mathrm{CO}_{2}$ during their lifetime, so despite the emission of $\mathrm{CO}_{2}$ during combustion, biogas may be considered as a $\mathrm{CO}_{2}$-neutral fuel [13]. The production of biogas also requires less processing effort and cost compared to other biofuels like alcohols and biodiesel [14-17]. Biogas holds great potential for developing economies with a rural background. For example, India has a cattle population of about 300 million, which is about $20 \%$ of the world total. About 980 million tonnes of cow dung are produced annually. This can potentially generate about 63.8 trillion litres of biogas, which in turn translates into 1.3 trillion MJ of energy [18-20].

Owing to the difference in the structural, proximate, and ultimate analyses results of biomass, some properties of the biogas samples such as the fractions of hydrogen, $\mathrm{CO}_{2}$, and sulphur and the ignition temperature vary from sample to sample [13]. Typically, biogas contains 25 to $40 \%$ carbon dioxide by volume [21]. Unless it is removed, it forms a highly corrosive acid on reacting with water, destroying pipelines, and equipment. Being non-combustible, carbon dioxide also reduces the heating value and energy density of biogas on volume basis and waste pipeline capacity. In addition, the presence of $\mathrm{CO}_{2}$ results in reduced flame velocity and flammability range compared to pure methane. Biogas resists knocking in SI engines by virtue of its high-self-ignition temperature [22]. However, this in turn makes ignition difficult in CI engines. A possible means of overcoming these drawbacks is to extract the $\mathrm{CO}_{2}$ content of biogas, thereby increasing the combustible fraction and making it a more viable alternative fuel $[6,7,23-26]$. This purification process is known as methane enrichment. In the light of these aspects, the present work discusses details of biogas production, methane enrichment (biogas purification) techniques, application of biogas in CI engines in two modes viz. dual fuel and HCCI, effect on engine performance and emissions, and numerical models available in published literature.

\section{METHODS AND MATERIALS}

\section{Biogas Production and Purification}

Various waste-to-energy (WTE) technologies for converting biological waste, e.g. industrial and municipal solid wastes (MSW) into biofuels have been investigated in recent years [14, 27, 28]. These methods can be broadly classified into four groups; a) hydrogenation, b) pyrolysis, c) gasification, and d) bioconversion. One of the most common means of producing biogas is using a digester, where anaerobic digestion of biomass generates biogas. Anaerobic digestion is a bioconversion process involving three stages viz. hydrolysis, acidification, and methane generation. The biogas obtained is thus predominantly a mixture of methane, $\mathrm{CO}_{2}$, and $\mathrm{H}_{2} \mathrm{~S}$ [21]. Some common properties of raw biogas are given in Table 1. Methane produced by anaerobic digestion has cost and efficiencies comparable to those of other biomass energy forms such as synthesised gases and ethanol [29]. Anaerobic digesters exist in various designs such as fixed dome type and floating drum type [21]. 
Table 1. Properties of biogas.

\begin{tabular}{|c|c|}
\hline Parameters description & Value \\
\hline $\begin{array}{l}\text { Composition of biogas (\% by volume) } \\
\text { [30] }\end{array}$ & $\begin{array}{l}\text { Methane }\left(\mathrm{CH}_{4}\right)=50 \text { to } 70 \\
\text { Carbon dioxide }\left(\mathrm{CO}_{2}\right)=25 \text { to } 50 \\
\text { Hydrogen }\left(\mathrm{H}_{2}\right)=1 \text { to } 5 \\
\text { Nitrogen }\left(\mathrm{N}_{2}\right)=0.3 \text { to } 3 \\
\text { Water vapour }\left(\mathrm{H}_{2} \mathrm{O}\right)=0.3 \\
\text { Hydrogen sulphide }\left(\mathrm{H}_{2} \mathrm{~S}\right) \text { in traces }\end{array}$ \\
\hline Auto-ignition temperature $(\mathrm{K}) *[31]$ & 1087 \\
\hline Calorific value $(\mathrm{MJ} / \mathrm{kg}) *[31]$ & 20.67 \\
\hline Density at $1 \mathrm{~atm} \& 288 \mathrm{~K}\left(\mathrm{~kg} / \mathrm{m}^{3}\right) *[31]$ & 0.91 \\
\hline $\begin{array}{l}\text { Stoichiometric air-fuel ratio ( } \mathrm{kg} \text { of air } / \mathrm{kg} \\
\text { of fuel) [32] }\end{array}$ & 6.05 \\
\hline Research octane number [30] & 130 \\
\hline Flame speed $(\mathrm{m} / \mathrm{s})[33]$ & 21 \\
\hline Flammability limit (vol. \% in air) [33] & $7.5-11.7$ \\
\hline
\end{tabular}

*: for biogas containing $60 \% \mathrm{CH}_{4}$ and $40 \% \mathrm{CO}_{2}$

Different methods have been used for purifying biogas by separating the unwanted species. Some of the commonly used physicochemical methods of separation involve water scrubbing, chemical reagents, molecular sieves, membranes, gas-liquid adsorption membranes, and cryogenic cooling. The conventionally used method of water scrubbing is a physical separation process, wherein compressed biogas is fed to the bottom of a packed column, and pressurised water is sprayed at the top, forming a counter-flow arrangement [34]. $\mathrm{CO}_{2}$ dissolves in water at high pressure and can be released later by lowering the pressure, enabling water recycling. Bhattacharya, Mishra, and Singh [35], Khapre [36] and Dubey [37] developed different scrubbing mechanisms offering a high degree of $\mathrm{CO}_{2}$ absorption. Vijay [18] developed a high pressure packed bed scrubber mechanism where up to $99 \%$ of $\mathrm{CO}_{2}$ was removed at an operating pressure of $1 \mathrm{MPa}$. Organic liquid reagents like Monoethanolamine (MEA), Diethanolamine (DEA), and Triethanolamine (TEA) can be used as solvents in place of water for absorbing $\mathrm{CO}_{2}$ and $\mathrm{H}_{2} \mathrm{~S}$, but this increases the equipment cost. Similarly, sodium or calcium hydroxide can also be used to absorb $\mathrm{CO}_{2}$ by forming the respective carbonate salts [38]. Biswas, Kartha, and Pundarikakhadu [39] demonstrated the effectiveness of chemical absorption using the reagent monoethanolamine, which can be regenerated by boiling. Savery and Cruzan [40] used a solution of $\mathrm{NaOH}, \mathrm{KOH}$, and $\mathrm{Ca}(\mathrm{OH})_{2}$ as the absorbing agent and found that turbulence generated by agitation enhanced the absorption capacity. Membrane separation technique has been in use for many years $[41,42]$. The basic principle of membrane separation is that some species present in the raw gas could pass through thin membranes of $\sim 1 \mathrm{~mm}$ thickness, while other species are retained. The difference in the partial pressures and permeability of species play an important role here. Molecules which are small and highly soluble in the membrane material permeate faster. Typically, when compressed biogas is fed to a polymer membrane, $\mathrm{CO}_{2}$ molecules permeate, whereas methane is retained. Pressures in the range 25-40 bar are required for the process. By comparing the performance of different membrane materials, Basu et al. [43] identified polymers like cellulose acetate, ethyl 
cellulose, silicon polycarbonate, polyimides, polysulfones, polydimethylsiloxane and polymethylpentene as the best suited for methane enrichment.

Molecular sieve method, also called Pressure Swing Adsorption (PSA) works based on the selective affinity of species for certain adsorbing materials. This technique involves three steps, viz. $\mathrm{CO}_{2}$ adsorption at a high pressure, regeneration after decompression, and pressure build-up for adsorption. Porous materials having high surface area such as activated carbon, alumina, silica gel and zeolites are used as adsorbents in PSA-systems [34]. One of the earliest reported studies involved a naturally occurring zeolite [44], wherein the breakthrough curves demonstrated good feasibility in methane enrichment. Pandey and Fabiani have used Neapolitan Yellow Tuff, a naturally occurring zeolite which acts as a molecular sieve to adsorb $\mathrm{CO}_{2}$. Cryogenic separation is carried out at a low temperature $\left(\sim-90^{\circ} \mathrm{C}\right)$ and high pressure $(\sim$ 40 bar) [34]. During this process, the $\mathrm{CO}_{2}$ fraction of biogas gets liquefied early on and is separated from the gaseous portion which is rich in methane. This method is still in the early stage of the research. One of the most recent developments in the area of biogas purification involves carbon nanotubes (CNTs). Liu et al. [45] used molecular dynamics to evaluate the $\mathrm{CO}_{2}$ permeability potential of CNTs. They predicted better performance in windowed CNT compared to ordinary CNT. Carbon nanotubes can also be potentially used as inorganic filler for mixed matrix membrane in biogas separation membranes as the nanomaterials enhance the yield and permeability [46].

Table 2. Comparison of biogas purification methods.

\begin{tabular}{|c|c|c|c|}
\hline Technique & References & Benefits & Disadvantages \\
\hline $\begin{array}{l}\text { Water } \\
\text { scrubbing }\end{array}$ & $\begin{array}{l}{[18,34-} \\
37]\end{array}$ & $\begin{array}{l}\text { Low } \mathrm{CH}_{4} \text { losses } \\
\text { High efficiency and } \\
\text { simple operation }\end{array}$ & $\begin{array}{l}\text { Expensive operation and } \\
\text { investment } \\
\text { High likelihood of } \\
\text { clogging }\end{array}$ \\
\hline $\begin{array}{l}\text { Chemical } \\
\text { reagents }\end{array}$ & {$[38-40]$} & $\begin{array}{l}\text { Low } \mathrm{CH}_{4} \text { losses } \\
\text { High efficiency and low } \\
\text { cost }\end{array}$ & $\begin{array}{l}\text { Expensive operation } \\
\text { High likelihood of } \\
\text { corrosion }\end{array}$ \\
\hline $\begin{array}{l}\text { Molecular } \\
\text { sieves }\end{array}$ & [44] & $\begin{array}{l}\text { Less energy usage } \\
\text { Compactness }\end{array}$ & $\begin{array}{l}\text { More } \mathrm{CH}_{4} \text { losses } \\
\text { Expensive operation }\end{array}$ \\
\hline Membranes & [41-43] & $\begin{array}{l}\text { Simple construction and } \\
\text { operation } \\
\text { Low cost }\end{array}$ & More $\mathrm{CH}_{4}$ losses \\
\hline $\begin{array}{l}\text { Cryogenic } \\
\text { cooling }\end{array}$ & {$[34]$} & High purity & Expensive operation \\
\hline
\end{tabular}

Table 2 shows a comparison of the various purification methods outlined above. Scrubbing and membrane separation do not need special equipment or chemicals to run and hence are the simplest processes to operate. While the operation of pressure swing adsorption is also quite simple, where the plant needs to be shut down several times annually to replace the catalyst as $\mathrm{H}_{2} \mathrm{~S}$ gradually poisons the adsorbent material. In contrast, the high pressure and very low temperatures required for cryogenic separation demand sophisticated equipment and thorough checking of insulation and sealing. Membrane separation offers a number of significant advantages such as compactness and modularity of devices. Membrane systems can be operated in mild conditions and 
are energy efficient on account of very low electricity and fuel consumption [34]. Mixed Matrix Membranes with CNT and silicon nanoparticles are still at research level.

\section{Applications Of Biogas}

In addition to direct combustion in burners and boilers, biogas has been used to power prime movers such as gas engines. There is an even greater potential for biogas if it can be utilised as a transportation fuel. The use of biogas in conventional SI and CI engines has been a topic of extensive research over the past few decades [1, 4, 47-51]. Table 3 illustrates the difference in composition of biogas used by various researchers. Biogas is commonly used in two modes of a CI engine which are discussed below.

Table 3. Composition of biogas used by various researchers.

\begin{tabular}{lc}
\hline \multicolumn{1}{c}{$\begin{array}{c}\text { Biogas composition (\% vol.) } \\
\mathrm{CH}_{4}: \mathrm{CO}_{2}\end{array}$} & References \\
\hline $57.37: 42.1$ & {$[52]$} \\
$60: 30$ & {$[47]$} \\
$60: 40$ & {$[31,32,53-56]$} \\
$73: 17.37$ & {$[33,57]$} \\
$73: 19$ & {$[58]$} \\
$30-73: 20-40$ & {$[50,59]$} \\
$50-70: 25-50$ & {$[30]$} \\
$95: 3 \& 65: 32$ & {$[48]$} \\
$59: 41,70: 30 \& 80: 20$ & {$[22]$} \\
$90: 10,80: 20,70: 30 \& 60: 40$ & {$[49]$} \\
$100: 0,70: 30,59.9: 40.1,49.7: 50.3 \& 39.9: 60.1$ & {$[60]$} \\
$100: 0,87.5: 12.5,75: 25$ and $50: 50$ & {$[61]$} \\
\hline
\end{tabular}

\section{Dual Fuel Mode}

In the dual fuel mode, biogas is mixed with air in the intake manifold and inducted into the engine cylinder, where it undergoes compression. Towards the top dead centre (TDC), a small quantity of diesel or bio-diesel termed as the pilot fuel is injected. The self-ignition of the pilot fuel initiates a flame which traverses the combustion chamber, consuming the biogas-air mixture. A comparison of combustion, performance and emission characteristics of CI engines operated on biogas in dual fuel mode vis-à-vis conventional diesel-only operation is presented below.

\section{Combustion Indices}

Dual fuel mode shows similar performance trends as those of an SI engine [53,62]. The energy release from the pilot diesel spray is several orders of magnitude higher than that of a spark, thus improving the ignitability of the inducted mixture. Compared to diesel operation, the biogas dual fuel mode has longer ignition delay on the account of the $\mathrm{CO}_{2}$ content causing a high initial heat release. Consequently, the cylinder peak pressure increases and occurs closer to the TDC with increase in biogas concentration [33, 50, 63]. Studies on an IDI engine with biogas in dual fuel mode with diesel substitution up to $48 \%$ indicated a reduction in combustion duration and consequently lower exhaust gas temperatures [58]. In a study involving biogas-diesel dual fuel operation, the maximum Net Heat Release Rate (NHRR) was observed to be around 30\% greater for the dual fuel mode compared to diesel-only mode under similar loading and speed 
conditions [64]. The increase in ID can be offset by using higher quantity of pilot fuel. However, for pure methane combustion, it is seen that the ID is nearly independent of the quantity of pilot fuel injected [65]. Bora et al. [31] observed that the quantity of pilot fuel supplied can be reduced by using high compression ratios because of the shorter ignition delay of biogas at elevated temperatures. They used compression ratios in the range of 16-18. The reduction in ignition delay can also be achieved by oxygen enrichment, i.e. by increasing the oxygen content of air. This improves the reaction rate and flame propagation. Raising the oxygen content in air from $21 \%$ to $27 \%$ has been reported to shorten the ignition delay by nearly $3{ }^{\circ} \mathrm{CA}$ [32]. Ignition delay is lower for thermal barrier coated dual fuel engine compared to normal dual fuel engine [66]. Methane enrichment increases cylinder peak pressure and combustion duration and reduces ignition delay [67].

Ray, Mohanty, and Mohanty [68] reported that the ignition delay of the pilot fuel is directly proportional to the ratio of biogas to diesel. Pilot diesel injection of around 10- $20 \%$ of the amount used in diesel-only mode is sufficient for dual fuel operation. Biogas supply requires to be regulated by means of a gas control valve depending on the load. The authors have noted that in governed engines, the control of the pilot fuel by the governor is enough to get the desired output. The diesel substitution is relatively low in such cases. Park and Yoon [69] compared diesel-biogas mode with diesel-gasoline mode. It was reported that an increase in port injection ratio leads to an increase in ignition delay compared to diesel-gasoline mode. Investigations by Königsson et al. [63] on a biogas-diesel dual fuel engine showed that by advancing the crank angle for $50 \%$ heat release, the average in-cylinder temperature and combustion efficiency can be enhanced. This also extends the lean limit of the engine. A similar effect can be achieved by increasing the inlet temperature. Up to $40 \%$ exhaust gas recirculation (EGR) can be used in dual fuel mode, while still allowing up to $95 \%$ diesel substitution. EGR reduces the lean operating limit and combustion efficiency. The use of EGR also favours near-stoichiometric operation. This allows the use of three-way catalyst, promising reduced after-treatment cost. Stoichiometric combustion with EGR and low inlet temperature is the recommended operating condition for dual fuel mode [63]. The use of biogas in a dual fuel engine with dimethyl ether (DME) as the pilot fuel was studied by Park et al. [59]. The proportion of biogas (on energy release basis) was varied from $0 \%$ (only DME) to $80 \%$. Higher biogas:DME ratio resulted in a fall in peak rate of heat release, burning rate, and cylinder pressure besides causing unstable combustion reflected as higher Coefficient of Variance (COV) of peak pressure. For injection earlier than $20^{\circ}$ bTDC, ignition delay was longer and start of ignition (SOI, defined as the crank angle of $10 \%$ of cumulative heat release) retarded for higher biogas energy ratio. However, both ignition delay and SOI were nearly independent of the biogas content for retarded injection.

Barik and team used Karanja methyl ester (KME) with biogas in dual fuel mode. They studied the effects of various concentrations of diethyl ether (DEE) as an ignition improver [70] and different injection timings [71]. Addition of DEE increases cylinder peak pressure and reduces combustion duration. Advancing the injection timing increases the ignition delay. Bora and Saha $[72,73]$ reported the effect of compression ratio in CI engine using rice bran biodiesel as pilot fuel and biogas as primary fuel at various compression ratios and injection timings. An increase in compression ratio increases cylinder peak pressure and reduces ignition delay. Cylinder peak pressure increases with advance in injection timings. 


\section{Performance Indices}

Bora et al. [31] and Yoon and Lee [50] reported a reduction in brake thermal efficiency and an increase in BSFC (Brake Specific Fuel Consumption) in dual fuel mode compared to diesel operation. This was attributed to early occurrence of peak pressure, low combustion temperature, and flame speed as well as higher pumping work due to the presence of $\mathrm{CO}_{2}$. Duc and Wattanavichien [58] operated an IDI engine with biogas in dual fuel mode with diesel substitution up to $48 \%$. Dual fuel and diesel modes showed almost equal fuel conversion efficiencies at full load operation whereas efficiency of the dual fuel mode was lower at part loads. Bora et al. [31] suggested increasing the compression ratio as a means to partially negate the reduction in brake thermal efficiency of the dual fuel mode. Simulated biogas is used by various researchers in dual fuel mode [56, 74-76]. Feroskhan and Ismail [77] used simulated biogas and reported that methane enrichment will enhance the brake thermal efficiency at low biogas flow rates. Mustafi et al. [64] also observed that the brake specific energy consumption of the biogas-diesel dual fuel and diesel-only modes was nearly the same. Sorathia and Yadav [78] also reported almost no deterioration in brake thermal efficiency in a CI engine operated in dual fuel mode with diesel and biogas. Percentage of fuel energy lost to the coolant was higher for dual fuel mode, whereas exhaust losses were lower. Exergy efficiency was found to be higher and percentage exergy destruction lower for the dual fuel mode. Raising the oxygen content in air from $21 \%$ to $27 \%$ has been reported to improve the brake thermal efficiency of a biogas-diesel dual fuel engine from 15 to $18 \%$ [32]. In a biogas-DME dual fuel engine, IMEP was observed to fall with an increase in biogas content for retarded pilot injection, whereas the trend was opposite for injection advance more than $20{ }^{\circ} \mathrm{bTDC}$ [59].

Experiments with different methane: $\mathrm{CO}_{2}$ ratios have indicated that a $7: 3$ ratio provides the highest brake thermal efficiency [62]. The authors attributed this to the dissociation of $\mathrm{CO}_{2}$ into $\mathrm{CO}$ and $\mathrm{O}_{2}$ due to the high temperature of the diesel flame. $\mathrm{CO}$ is a fast burning gas, hence accelerating the burning rate. The additional oxygen concentration also improves combustion. However, for higher $\mathrm{CO}_{2}$ content, the dilution effect dominates and lowers the thermal efficiency. Sahoo, Sahoo, and Saha [79] reviewed various works dealing with dual fuel gas diesel engines. They confirmed that biogas containing up to $20-30 \% \mathrm{CO}_{2}$ offers lower BSFC compared to diesel-natural gas operation, whereas BSFC increases with further increase in $\mathrm{CO}_{2}$ content on account of the inert gas effect. For above $40 \% \mathrm{CO}_{2}$, the engine operation becomes rough due to irregular combustion. For increasing $\mathrm{CO}_{2}$ content, the engine speed and power can be maintained by increasing either the biogas or the pilot fuel flow rate. Compared to diesel-only operation, the dual fuel mode results in marginally lower volumetric efficiency on account of the displacement of air. This effect is enhanced by increasing the carbon dioxide fraction of biogas. Luijten and Kerkhof [60] observed that with biogas containing $70 \%$ methane, the volumetric efficiency dropped from $95 \%$ for the diesel mode to $91-92 \%$ for dual fuel operation, when the energy released from diesel and biogas were equal. They also noted that while biogas with $70 \%$ methane can substitute up to $55 \%$ diesel on energy release basis, the substitution was limited to $35 \%$ for biogas with $40 \%$ methane. Light end gas knock was reported for high methane:diesel ratio [60]. Addition of $\mathrm{CeO}_{2}$ nanoparticles in diesel, EGR, split injection, and induction of hydrogen in dual fuel mode increase brake thermal efficiency $[80,81]$.

Barik and Sivalingam [82] worked on a biogas-diesel dual fuel engine where the pilot fuel flow rate was controlled by the governor and the biogas flow rate was varied 
manually from $0-0.6 \mathrm{~kg} / \mathrm{h}$. At full load, the maximum diesel substitution (on energy basis) was $30 \%$. Volumetric efficiency was reported to be lower and brake specific energy consumption higher for dual fuel mode as the $\mathrm{CO}_{2}$ displaces air and deteriorates the burning rate. Barik and Murugan [33] also noted a reduction in volumetric and brake thermal efficiencies on increasing the biogas flow rate. Increase of DEE concentration in KME-biogas has been shown to reduce brake thermal efficiency and exhaust gas temperature and increase BSFC of a dual fuel engine [70]. Advancing injection timing increases brake thermal efficiency and exhaust gas temperature and reduces BSFC. Optimum injection timing is reported as $24.5^{\circ} \mathrm{CA}$ bTDC[71]. An increase in compression ratio of rice bran biodiesel-based dual fuel engine increases brake thermal efficiency and volumetric efficiency and reduces BSFC and exhaust gas temperature [72].

\section{Emission Indices}

The low temperatures are caused by the presence of $\mathrm{CO}_{2}$ in biogas augment $\mathrm{CO}$ and unburned hydrocarbon (UHC) emissions, while oxides of nitrogen $\left(\mathrm{NO}_{\mathrm{x}}\right)$ and particulate matter (PM) emissions are less compared to diesel mode [33, 50, 53, 62]. Barik and Sivalingam [82] found that exhaust gas temperature was lower by $2.8 \%, \mathrm{CO}$ and $\mathrm{HC}$ higher by $16 \%$ and $21 \%$, respectively, while $\mathrm{NO}_{\mathrm{x}}$ and soot lower by $35 \%$ and $41.3 \%$, respectively, as compared to diesel operation for maximum diesel substitution at full load. At higher $\mathrm{CO}_{2}$ fractions, it remained undissociated, thereby acting as an inert gas and reducing the thermal efficiency. $\mathrm{NO}_{\mathrm{x}}$ emissions decrease with the increasing $\mathrm{CO}_{2}$ content of biogas, similar to the effect produced by EGR. CO and $\mathrm{HC}$ emissions can be brought down by increasing the compression ratio by virtue of the higher temperatures. However, this causes a notable increase in $\mathrm{CO}_{2}$ and $\mathrm{NO}_{\mathrm{x}}$ emissions [31]. The extent of variation of these parameters can be controlled by adjusting the pilot diesel injection quantity [64, 65]. Barik and Murugan [33] observed that a biogas flow rate of $0.9 \mathrm{~kg} / \mathrm{h}$ provided the optimum combination of performance and emissions. This corresponds to the replacement of $0.215 \mathrm{~kg} / \mathrm{h}$ of diesel.

Oxygen enrichment lowers the methane emissions. $\mathrm{CO}$ emissions do not show a definite trend. By attenuating combustion instabilities, oxygen enrichment allows greater substitution of diesel by biogas [32]. EGR reduces the lean operating limit and combustion efficiency, while $\mathrm{NO}_{\mathrm{x}}$ emissions are lowered. $\mathrm{NO}_{\mathrm{x}}$ formation can be attributed to the pilot diesel spray for lean mixtures $(\lambda>1.6)$ and to the high temperature combustion of methane-air mixture under rich conditions [63].

Biogas in a dual fuel engine with DME as the pilot fuel reduced indicated specific $\mathrm{NO}_{\mathrm{x}}$ emissions, while ISHC and ISCO emissions increased upon increasing the proportion of biogas. Soot emissions were close to zero [59]. In a dual fuel engine operated with biogas and Karanja Methyl Ester (KME) as pilot, it was observed that about $22 \%$ replacement of the pilot fuel was possible with a biogas flow rate of $0.9 \mathrm{~kg} / \mathrm{h}$ at full load. The study also showed that $\mathrm{NO}_{\mathrm{x}}$ and $\mathrm{PM}$ emissions can be simultaneously reduced for the dual fuel operation, though $\mathrm{CO}$ and $\mathrm{HC}$ emissions increased [57]. Effects of DEE in KME-biogas dual fuel mode were reported by Barik and team [70]. An increase in DEE reduces $\mathrm{CO}, \mathrm{NO}_{x}$, and smoke emissions. However, it increases HC emissions. Optimum injection timing is reported as $24.5^{\circ} \mathrm{CA}$ bTDC with reduction of $17.1 \% \mathrm{CO}$ emission, $18.2 \% \mathrm{HC}$ emission, and $2.1 \%$ smoke emission compared to $23^{\circ} \mathrm{CA}$ bTDC [71]. Thermal barrier coated dual fuel engine is used to reduce the smoke emissions [66]. An increase in $\mathrm{CO}_{2}$ fraction reduces $\mathrm{NO}_{\mathrm{x}}$ and smoke but, increases $\mathrm{HC}$ and $\mathrm{CO}$ emissions [67]. An increase of compression ratio and injection timings in rice 
bran biodiesel based dual fuel engine reduces $\mathrm{CO}$ and $\mathrm{HC}$ emissions and increases $\mathrm{CO}_{2}$ and $\mathrm{NO}_{\mathrm{x}}$ emissions $[72,73]$. A summary of the effects of increasing biogas flow rate on various combustion, performance, and emission parameters vis-à-vis conventional diesel operation is presented in Table 4.

Table 4. Effect of increasing biogas flow rate on engine parameters in dual fuel mode.

\begin{tabular}{lll}
\hline Parameter & Effect & References \\
\hline Ignition delay & Increases & {$[32,33,50]$} \\
Maximum heat release rate & Increases & {$[32,33,50]$} \\
Cylinder Pressure & Increases & {$[32,33,50]$} \\
Exhaust Temperature & Decreases & {$[58]$} \\
Brake Thermal Efficiency & Decreases & {$[31,50]$} \\
Specific Brake Fuel Consumption & Increases & {$[31,50]$} \\
Volumetric Efficiency & Decreases & {$[60]$} \\
NO Emisssion & Decreases & {$[50,53,62]$} \\
Particulate Matter & Decreases & {$[50,53,62]$} \\
HC Emission & Increases & {$[50,53,62]$} \\
CO Emission & Increases & {$[50,53,62]$} \\
Combustion Duration & Decreases & {$[58]$} \\
Fuel Energy Conversion Efficiency & Same & {$[64]$} \\
Combustion efficiency & Increases & {$[63]$} \\
Lean Limit & Increases & {$[31,50]$} \\
Flame Speed & Decreases & {$[31,50]$} \\
BSEC & Increases & {$[82]$} \\
\hline
\end{tabular}

\section{HCCI Engine}

An alternative approach for using biogas in a CI engine is the Homogeneous Charged Compression Ignition (HCCI) mode. This has emerged as a promising concept combining the benefits of SI and CI engines [83]. Biogas can be effectively used in the HCCI mode by introducing it into the intake manifold. This allows the fuel and air to be completely mixed prior to combustion and the mixture auto-ignites as a result of the temperature rise during the compression stroke. HCCI engines offer high thermal efficiencies on account of low equivalence ratios and rapid energy release. These conditions also ensure low $\mathrm{NO}_{\mathrm{x}}$ and particulate emissions [83]. In spite of these benefits, a major drawback of HCCI engines is that the user has no direct control over the onset of combustion unlike conventional SI or CI engines. Various means of controlling combustion such as pilot diesel injection, spark, charge preheating, exhaust gas recirculation (EGR), fast thermal management, turbocharging, fuel reactivity control, and variable compression ratio have been employed [83-86].

\section{Combustion Indices}

The research groups $[53,54,87](2007,2009$, and 2010) studied the performance of an HCCI engine when fuelled with diesel and with a biogas-diesel mixture. A comparison with biogas-diesel dual fuel mode was also presented. In the diesel HCCI case, incylinder injection timing was varied from $5^{\circ}$ bTDC to $20^{\circ}$ aTDC during suction. Stable operation was achieved only for injection after TDC during suction. BMEP was varied in the range of 2.15 to 4.32 bar. Very high heat release rates were observed at higher BMEP conditions because of rapid combustion [87]. In the biogas-diesel HCCI mode, 
manifold injection was employed for both fuels. Biogas ratio, charge temperature and BMEP were varied. It was found that the presence of $\mathrm{CO}_{2}$ and higher self-ignition temperature of $\mathrm{CH}_{4}$ increased the ignition delay. Subsequent heat release rate was found to be within safe limits compared to the diesel HCCI mode. Lower amount of biogas produced knocking and higher amounts led to misfire [53, 54]. Biogas-diesel HCCI operation provided higher heat release rates compared to biogas-diesel dual fuel mode for the same biogas:diesel ratio.

Ibrahim et al. [30] investigated biogas-diesel PPCCI (predominantly premixed charge compression ignition) mode. Biogas was inducted and in-cylinder diesel injections with very advanced timings were employed to attain conditions similar to HCCI. The effects of injection timing, intake charge temperature, and biogas energy ratio were studied. The best injection timing, intake charge temperature, and biogas energy ratio were found to be $55-70{ }^{\circ} \mathrm{BTDC}, 50-90{ }^{\circ} \mathrm{C}$. and $80 \%$, respectively. By advancing the diesel injection timing, the homogeneity of the lean mixtures was enhanced. This resulted in delayed combustion and lower energy release rates [30].

The effects of charge temperature, boost pressure, and equivalence ratio were investigated by Bedoya et al. [55] using a biogas fuelled 4-cylinder engine in HCCI mode. It was reported that higher inlet pressures and temperatures reduce the selfignition temperature and provide higher burning rates [56]. Jun and Iida [88] reported that increasing the in-cylinder temperature improves the combustion efficiency. An increase in $\mathrm{CO}_{2}$ fraction of biogas enhances the BMEP without the adverse effect of knocking [89].

\section{Performance Indices}

Compared to conventional CI mode, thermal efficiency is lowered by nearly $40 \%$ in the diesel HCCI mode because of wall wetting and improper combustion phasing [87]. While the use of biogas normally causes a drop in thermal efficiency in both SI and CI engines, it is observed to maintain high thermal efficiency in HCCI mode [54]. Swaminathan et al. [53] showed that biogas-diesel HCCI mode offers poorer brake thermal efficiency compared to dual fuel mode in general but the efficiency can be improved by preheating the intake to about $135^{\circ} \mathrm{C}$ and using higher biogas energy ratios. The highest brake thermal efficiency in PPCCI mode was obtained with a biogas energy ratio of $80 \%$ [30]. Power output and indicated efficiency can be enhanced by increasing inlet pressure and charge temperature for lean mixtures [56]. Sudheesh and Mallikarjuna [52] explored the use of diethyl ether (DEE) as an ignition improver for biogas combustion in HCCI engines. They showed that biogas-DEE in HCCI mode offers wider operating load range and higher brake thermal efficiency at all loads compared to biogas-diesel dual fuel and biogas SI operation. Different strategies have been experimentally evaluated by Bedoya et al. [55] in order to extend the operating range of a biogas fuelled HCCI engine and ensure safe operation and stable combustion. Oxygen enrichment at constant biogas flow rates and gasoline pilot injection were separately tested at the low load limit. Delayed combustion phasing was tested at high load limit. The operating range of equivalence ratios for stable combustion was identified as 0.2 0.5. Employing a free piston arrangement has been proposed as a strategy to enable the use of extremely lean mixtures in HCCI engines [90].

\section{Emission indices}

Swaminathan et al. [87] noted that compared to conventional CI operation, $\mathrm{NO}_{\mathrm{x}}$ emissions were lower in diesel HCCI mode. This is attributed to lower operating 
temperatures in the latter case. However, diesel HCCI mode had higher smoke, HC, and $\mathrm{CO}$ emissions. Impingement of the fuel on the cylinder wall leading to nonhomogeneous mixtures and improper combustion was pointed out as the major reasons for the increase in emissions. Higher $\mathrm{HC}$ emissions could also be the result of the fuel escaping through the exhaust port during the valve overlap period at advanced injection timings. In subsequent studies, they showed that biogas-diesel HCCI mode has lower $\mathrm{NO}_{\mathrm{x}}$ and smoke compared to dual fuel and CI modes [53, 54]. Considering both performance and emission aspects, they recommended CI, biogas-diesel HCCI, and dual fuel operation for low, moderate, and high loads respectively. On brake specific basis, $\mathrm{NO}$, smoke, HC, and CO in PPCCI mode were found to be comparable to those of dual fuel mode [30]. Low $\mathrm{HC}$ and $\mathrm{CO}$ emissions were reported for lean mixtures at increased inlet temperature and charge pressure [55]. Jun and Iida [88] observed that CO emissions can be reduced by increasing in-cylinder temperature in natural gas-based HCCI engines. Biogas in HCCI mode produces lower HC emissions compared to SI mode [52]. Kozarac et al. [91] reported that biogas-based HCCI engine with n-heptane as ignition promoter lowers $\mathrm{NO}_{\mathrm{x}}$ emission. Reducing methane fraction in biogas leads to better BHC emission [89].

\section{Simulation}

Simulation of the IC engine operating cycle helps us in gaining better understanding of the effects of various physicochemical parameters on performance and emissions. The mathematical models used in simulations can be classified as single-zone, multi-zone, probability-based, and multi-dimensional models [8]. Compared to the large number of articles in published literature dealing with the modelling of conventional engines, works pertaining to dual fuel and HCCI engines, particularly those operated on biogas are scarce. The following paragraph summarises simulation methodologies of various degrees of complexity followed for dual fuel and HCCI engines in general.

For the closed part of the cycle, the simplest approach is to use a zerodimensional single zone model. Such a model has been developed for diesel [92] and natural gas [93]. One of the major drawbacks of these models is that the underlying assumption of uniform gas temperature reduces the accuracy of prediction of heat release rate, duration of combustion, and emissions. This can be overcome to an extent by employing quasi-dimensional or multi-zone models. Here the cylinder contents are divided into two or more finite number of homogeneous zones, each having uniform composition and thermodynamic state. Heat, work, and mass exchanges between zones are also accounted for. While quasi-dimensional models combine accuracy with computational efficiency, one drawback is their inability to describe mixture stratification/heterogeneity, which requires specification of the conditions within each zone. In the CFD models, the requisite governing equations are solved for all the zones or cells, providing a more accurate but computationally expensive solution. Two CFDbased approaches exist. In the first one, the CFD code solves the governing equations without considering chemical reactions. The velocity and temperature fields thus predicted provides the input to an equivalent multi-zone model which uses a chemical kinetics solver to update the temperature and species concentration [94]. Alternatively, a simultaneous solution of all governing equations can be performed in the CFD solver considering reaction kinetics in all cells [95]. Computational requirements can be minimised by employing reduced reaction mechanisms [96]. CFD models are also classified as 2D [97] and 3D [94-96, 98-100]. Mosbach et al. [101] used a stochastic 
reactor model based on probability density functions (PDFs) to study the HCCI combustion of biofuel blends.

Visakhamoorthy et al. [102] used a multi-zone model to predict the pressure history, energy release, and emissions in a diesel engine adapted to operate on simulated biogas in HCCI mode. The multi-zone model comprises an interior core surrounded by nine annular zones. Simulation was carried out from IVC to EVO using a parallelised Fortran code. The zones were treated as stirred constant volume reactors wherein the chemical kinetics was modelled using CHEMKIN. They reported good predictions of pressure history and energy release rate, except close to the misfire limit. Awate et al. [103] carried out numerical simulation of an HCCI engine using a zero dimensional single zone model and CHEMKIN. They studied the effects of initial temperature, equivalence ratio, engine speed, and compression ratio on ignition timing and peak pressure.

\section{CONCLUSIONS}

Biogas holds several advantages as an alternative fuel. In order to make it viable for use in engines, biogas needs to be purified by removing its non-combustible constituents such as $\mathrm{CO}_{2}$ - a process known as methane enrichment. Various techniques used for purifying biogas have been explained and their pros and cons summarised. The state of the art in the utilisation of biogas in CI engines in dual fuel and HCCI modes and the influence on performance and emissions were discussed in the light of existing literature and compared to the trends of conventional diesel fuelled CI engines. Simulation methodologies pertinent to dual fuel and HCCI operating modes were also reviewed. Advanced biogas purification techniques are such as nanotechnology based membranes and cryogenic separation, development of on-board purification techniques to improve the viability of biogas as an automotive fuel, HCCI engines operated on biogas, simulation of biogas fuelled engines, and combustion control methods for HCCI engines.

\section{ACKNOWLEDGEMENTS}

The authors would like to thank VIT Chennai and DST-SERB for supporting our research on biogas fuelled CI engines via the university research seed fund and extramural research scheme respectively. This was our main motivation for undertaking an extensive study on the biogas production, purification and use in CI engines.

\section{REFERENCES}

[1] Mihic S. Biogas fuel for internal combustion engines. Annals of Faculty Engineering Hunedoara. 2004;2:179-90.

[2] Murugesan A, Umarani C, Subramanian R, Nedunchezhian N. Bio-diesel as an alternative fuel for diesel engines-A review. Renewable and Sustainable Energy Reviews. 2009;13:653-62.

[3] Agarwal AK. Biofuels (alcohols and biodiesel) applications as fuels for internal combustion engines. Progress in Energy and Combustion Science. 2007;33:23371. 
[4] Qian Y, Sun S, Ju D, Shan X, Lu X. Review of the state-of-the-art of biogas combustion mechanisms and applications in internal combustion engines. Renewable and Sustainable Energy Reviews. 2017;69:50-8.

[5] Visconti P, Primiceri P, Strafella L, Carlucci AP, Ficarella A. Morphological analysis of injected sprays of different bio-diesel fuels by using a common rail setup controlled by a programmable electronic system. International Journal of Automotive and Mechanical Engineering. 2017;14:3849-71.

[6] Saifuddin N, Refal H, Kumaran P. Performance and emission characteristics of micro gas turbine engine fuelled with bioethanol-diesel-biodiesel blends. International Journal of Automotive and Mechanical Engineering. 2017;14:4030-49.

[7] Jaichandar S, Annamalai K. Jatropha oil methyl ester as diesel engine fuel - an experimental investigation. International Journal of Automotive and Mechanical Engineering. 2016;13:3248-61.

[8] Komninos N, Rakopoulos C. Modeling HCCI combustion of biofuels: a review. Renewable and Sustainable Energy Reviews. 2012;16:1588-610.

[9] Nayak S, Mishra P. Emission from a dual fuel operated diesel engine fuelled with Calophyllum Inophyllum biodiesel and producer gas. International Journal of Automotive and Mechanical Engineering. 2017;14(1).

[10] Bhaskar K, Sendilvelan S, Muthu V, Aravindraj S. Performance and emission characteristics of compression ignition engine using methyl ester blends of jatropha and fish oil. Journal of Mechanical Engineering and Scienes. 2016;10:1984-97.

[11] Bae C, Kim J. Alternative fuels for internal combustion engines. Proceedings of the Combustion Institute. 2017;36:3389-413.

[12] Tippayawong N, Thanompongchart P. Biogas quality upgrade by simultaneous removal of CO 2 and H 2 S in a packed column reactor. Energy. 2010;35:45315 .

[13] Demirbas A. Combustion characteristics of different biomass fuels. Progress in Energy and Combustion Science. 2004;30:219-30.

[14] Demirbas MF, Balat M, Balat H. Biowastes-to-biofuels. Energy Conversion and Management. 2011;52:1815-28.

[15] Shukri MR, Rahman MM, Ramasamy D, Kadirgama K. Artificial Neural Network Optimization Modeling on Engine Performance of Diesel Engine Using Biodiesel Fuel. International Journal of Automotive and Mechanical Engineering. 2015;11:2332-47.

[16] Khalid A, Jaat N, Sapit A, Razali A, Manshoor B, Zaman I, et al. Performance and Emissions Characteristics of Crude Jatropha Oil Biodiesel Blends in a Diesel Engine. International Journal of Automotive and Mechanical Engineering. 2015;11:2447-57.

[17] Azad AK, Rasul MG, Mofijur M, Bhuiya MMK, Mondal SK, Sattar MK. Energy and Waste Management for Petroleum Refining Effluents: A Case Study in Bangladesh. International Journal of Automotive and Mechanical Engineering. 2015;11:2170-87.

[18] Vijay VK. Biogas refining for production of bio-methane and its bottling for automotive applications and holistic development. Proceeding of International Symposium on Eco Topia Science, ISETS072007.

[19] Mohd Noor CW, Mamat R, Najafi G, Mat Yasin MH, Ihsan CK, Noor MM. Prediction of marine diesel engine performance by using artificial neural 
network model. Journal of Mechanical Engineering and Sciences. 2016;10:191730 .

[20] Said NH, Ani FN, Said MFM. Review of the production of biodiesel from waste cooking oil using solid catalysts. Journal of Mechanical Engineering and Sciences. 2015;8:1302-11.

[21] Khoiyangbam R, Gupta N, Kumar S. Biogas Technology: towards sustainable development: The Energy and Resources Institute (TERI); 2011.

[22] Porpatham E, Ramesh A, Nagalingam B. Investigation on the effect of concentration of methane in biogas when used as a fuel for a spark ignition engine. Fuel. 2008;87:1651-9.

[23] Ryckebosch E, Drouillon M, Vervaeren H. Techniques for transformation of biogas to biomethane. Biomass and bioenergy. 2011;35:1633-45.

[24] Nayak SK, Mishra PC. Emission from a dual fuel operated diesel engine fuelled with Calophyllum Inophyllum biodiesel and producer gas. International Journal of Automotive and Mechanical Engineering. 2017;14:3954-69.

[25] Patil KR, Thipse SS. The effect of injection timing on the performance and emission of direct injection CI engine running on diethyl ether-diesel blends. International Journal of Automotive and Mechanical Engineering. 2016;13:3773-87.

[26] Sathiyamoorthi R, Sankaranarayanan G. Fuel Injection Timings of a Direct Injection Diesel Engine Running on Neat Lemongrass Oil-Diesel Blends. International Journal of Automotive and Mechanical Engineering. 2015;11:2348-63.

[27] Gunaseelan VN. Anaerobic digestion of biomass for methane production: a review. Biomass and bioenergy. 1997;13:83-114.

[28] Ahamed J, Raiyan M, Hossain M, Rahman M, Salam B. Production of biogas from anaerobic digestion of poultry droppings and domestic waste using catalytic effect of silica gel. International Journal of Automotive \& Mechanical Engineering. 2016;13.

[29] Chynoweth DP, Owens JM, Legrand R. Renewable methane from anaerobic digestion of biomass. Renewable Energy. 2001;22:1-8.

[30] Ibrahim MM, Narasimhan JV, Ramesh A. Comparison of the predominantly premixed charge compression ignition and the dual fuel modes of operation with biogas and diesel as fuels. Energy. 2015;89:990-1000.

[31] Bora BJ, Saha UK, Chatterjee S, Veer V. Effect of compression ratio on performance, combustion and emission characteristics of a dual fuel diesel engine run on raw biogas. Energy Conversion and Management. 2014;87:10009.

[32] Cacua K, Amell A, Cadavid F. Effects of oxygen enriched air on the operation and performance of a diesel-biogas dual fuel engine. Biomass and bioenergy. 2012;45:159-67.

[33] Barik D, Murugan S. Investigation on combustion performance and emission characteristics of a DI (direct injection) diesel engine fueled with biogas-diesel in dual fuel mode. Energy. 2014;72:760-71.

[34] de Hullu J, Maassen J, van Meel P, Shazad S, Vaessen J. Biogas upgrading, comparing different techniques. Eindhoven, Netherlands. 2008.

[35] Bhattacharya T, Mishra T, Singh B. Techniques for removal of CO2 and H2S from biogas. XXIV annual convention of ISAE, held at PKV, Akola1988. 
[36] Khapre U. Studies on biogas utilization for domestic cooking. XXV annual convention of ISAE, held at CTAE, Udaipur1989.

[37] Dubey A. Wet scrubbing of carbon dioxide. Annual report of CIAE, Bhopal (India). 2000.

[38] Nijaguna B. Biogas technology: New Age International; 2006.

[39] Biswas T, Kartha A, Pundarikakhadu R. Removal of carbon dioxide from biogas. Proceedings of national symposium on biogas technology and uses New Delhi: IARI1977.

[40] Savery CW, Cruzan DC. Methane recovery from chicken manure digestion. Journal (Water Pollution Control Federation). 1972:2349-54.

[41] Guha AK, Majumdar S, Sirkar KK. A larger-scale study of gas separation by hollow-fiber-contained liquid membrane permeator. Journal of Membrane Science. 1991;62:293-307.

[42] $\mathrm{Li} \mathrm{K}$, Teo W. Use of an internally staged permeator in the enrichment of methane from biogas. Journal of Membrane Science. 1993;78:181-90.

[43] Basu S, Khan AL, Cano-Odena A, Liu C, Vankelecom IF. Membrane-based technologies for biogas separations. Chemical Society Reviews. 2010;39:75068.

[44] Pande D, Fabiani C. Feasibility studies on the use of a naturally occurring molecular sieve for methane enrichment from biogas. Gas Separation \& Purification. 1989;3:143-7.

[45] Liu H, Cooper VR, Dai S, Jiang D-e. Windowed carbon nanotubes for efficient $\mathrm{CO} 2$ removal from natural gas. The Journal of Physical Chemistry Letters. 2012;3:3343-7.

[46] Seno J, I N W. The uses of carbon nanotubes mixed matrix membranes (MMM) for biogas purification. International Journal of Waste Resources (IJWR). 2012;2.

[47] Porpatham E, Ramesh A, Nagalingam B. Effect of compression ratio on the performance and combustion of a biogas fuelled spark ignition engine. Fuel. 2012;95:247-56.

[48] Chandra R, Vijay V, Subbarao P, Khura T. Performance evaluation of a constant speed IC engine on CNG, methane enriched biogas and biogas. Applied Energy. 2011;88:3969-77.

[49] Xin Z, Jian X, Shizhuo Z, Xiaosen H, Jianhua L. The experimental study on cyclic variation in a spark ignited engine fueled with biogas and hydrogen blends. International Journal of Hydrogen Energy. 2013;38:11164-8.

[50] Yoon SH, Lee CS. Experimental investigation on the combustion and exhaust emission characteristics of biogas-biodiesel dual-fuel combustion in a CI engine. Fuel Processing Technology. 2011;92:992-1000.

[51] Von Mitzlaff K. Engines for biogas. German Appropriate Technology Exchange (GATE), Deutsche Gesellschaft für Technische Zusammenarbeit (GTZ). 1988.

[52] Sudheesh K, Mallikarjuna J. Diethyl ether as an ignition improver for biogas homogeneous charge compression ignition (HCCI) operation-An experimental investigation. Energy. 2010;35:3614-22.

[53] Swami Nathan S, Mallikrajuna J, Ramesh A. Homogeneous charge compression ignition versus dual fuelling for utilizing biogas in compression ignition engines. Proceedings of the Institution of Mechanical Engineers, Part D: Journal of Automobile Engineering. 2009;223:413-22. 
[54] Nathan SS, Mallikarjuna J, Ramesh A. An experimental study of the biogasdiesel HCCI mode of engine operation. Energy Conversion and Management. 2010;51:1347-53.

[55] Bedoya ID, Saxena S, Cadavid FJ, Dibble RW, Wissink M. Experimental evaluation of strategies to increase the operating range of a biogas-fueled HCCI engine for power generation. Applied Energy. 2012;97:618-29.

[56] Bedoya ID, Saxena S, Cadavid FJ, Dibble RW, Wissink M. Experimental study of biogas combustion in an HCCI engine for power generation with high indicated efficiency and ultra-low NOx emissions. Energy Conversion and Management. 2012;53:154-62.

[57] Barik D, Sivalingam M. Investigation on performance and exhaust emissions characteristics of a DI diesel engine fueled with Karanja methyl ester and biogas in dual fuel mode. SAE Technical Paper; 2014.

[58] Duc PM, Wattanavichien K. Study on biogas premixed charge diesel dual fuelled engine. Energy Conversion and Management. 2007;48:2286-308.

[59] Park SH, Yoon SH, Cha J, Lee CS. Mixing effects of biogas and dimethyl ether (DME) on combustion and emission characteristics of DME fueled high-speed diesel engine. Energy. 2014;66:413-22.

[60] Luijten C, Kerkhof E. Jatropha oil and biogas in a dual fuel CI engine for rural electrification. Energy Conversion and Management. 2011;52:1426-38.

[61] Feroskhan M, Ismail S. Evaluating the effect of intake parameters on the performance of a biogas-diesel dual-fuel engine using the Taguchi method. Biofuels. 2017:1-9.

[62] Lounici MS, Loubar K, Tazerout M, Balistrou M, Tarabet L. Experimental Investigation on the Performance and Exhaust Emission of Biogas-Diesel DualFuel Combustion in a CI Engine. SAE Technical Paper; 2014.

[63] Königsson F, Stalhammar P, Angstrom H-E. Characterization and potential of dual fuel combustion in a modern diesel engine. SAE Technical Paper; 2011.

[64] Mustafi NN, Raine RR, Verhelst S. Combustion and emissions characteristics of a dual fuel engine operated on alternative gaseous fuels. Fuel. 2013;109:669-78.

[65] Polk A, Gibson C, Shoemaker N, Srinivasan K, Krishnan S. Analysis of ignition behavior in a turbocharged direct injection dual fuel engine using propane and methane as primary fuels. Journal of Energy Resources Technology. 2013;135:032202.

[66] Yilmaz I, Gumus M. Investigation of the effect of biogas on combustion and emissions of TBC diesel engine. Fuel. 2017;188:69-78.

[67] Verma S, Das L, Kaushik S. Effects of varying composition of biogas on performance and emission characteristics of compression ignition engine using exergy analysis. Energy Conversion and Management. 2017;138:346-59.

[68] Ray N, Mohanty M, Mohanty R. A Study on application of biogas as fuel in compression ignition engines. International Journal of Innovations in Engineering and Technology (IJIET). 2013;3:239-45.

[69] Park SH, Yoon SH. Effect of dual-fuel combustion strategies on combustion and emission characteristics in reactivity controlled compression ignition (RCCI) engine. Fuel. 2016;181:310-8.

[70] Barik D, Murugan S. Effects of diethyl ether (DEE) injection on combustion performance and emission characteristics of Karanja methyl ester (KME)-biogas fueled dual fuel diesel engine. Fuel. 2016;164:286-96. 
[71] Barik D, Murugan S, Sivaram N, Baburaj E, Sundaram PS. Experimental investigation on the behavior of a direct injection diesel engine fueled with Karanja methyl ester-biogas dual fuel at different injection timings. Energy. 2017;118:127-38.

[72] Bora BJ, Saha UK. Experimental evaluation of a rice bran biodiesel-biogas run dual fuel diesel engine at varying compression ratios. Renewable Energy. 2016;87:782-90.

[73] Bora BJ, Saha UK. Estimating the Theoretical Performance Limits of a Biogas Powered Dual Fuel Diesel Engine Using Emulsified Rice Bran Biodiesel as Pilot Fuel. Journal of Energy Resources Technology. 2016;138:021801.

[74] Feroskhan M, Saleel I. Evaluating the Influence of Biogas Flow Rate and Addition of Cerium Oxide Nanoparticles on the Performance of a Dual Fuel Engine Using Taguchi Method. Nano Hybrids and Composites. 2017;17:179-93.

[75] Kalsi SS, Subramanian K. Effect of simulated biogas on performance, combustion and emissions characteristics of a bio-diesel fueled diesel engine. Renewable Energy. 2017;106:78-90.

[76] Henham A, Makkar M. Combustion of simulated biogas in a dual-fuel diesel engine. Energy Conversion and Management. 1998;39:2001-9.

[77] Feroskhan M, Ismail S. Investigation of the effects of biogas composition on the performance of a biogas-diesel dual fuel CI engine. Biofuels. 2016;7:593-601.

[78] Sorathia HS, Yadav HJ. Energy Analyses to a CI-Engine using Diesel and Biogas Dual Fuel-a Review Study. world. 2012;1:5.

[79] Sahoo B, Sahoo N, Saha U. Effect of engine parameters and type of gaseous fuel on the performance of dual-fuel gas diesel engines-A critical review. Renewable and Sustainable Energy Reviews. 2009;13:1151-84.

[80] Feroskhan M, Ismail S, Kumar A, Kumar V, Aftab SK. Investigation of the effects of biogas flow rate and cerium oxide addition on the performance of a dual fuel CI engine. Biofuels. 2016;8:197-205.

[81] Shan X, Qian Y, Zhu L, Lu X. Effects of EGR rate and hydrogen/carbon monoxide ratio on combustion and emission characteristics of biogas/diesel dual fuel combustion engine. Fuel. 2016;181:1050-7.

[82] Barik D, Sivalingam M. Performance and emission characteristics of a biogas fueled DI diesel engine. SAE Technical Paper; 2013.

[83] Yao M, Zheng Z, Liu H. Progress and recent trends in homogeneous charge compression ignition (HCCI) engines. Progress in Energy and Combustion Science. 2009;35:398-437.

[84] Christensen M, Johansson B. Supercharged homogeneous charge compression ignition (HCCI) with exhaust gas recirculation and pilot fuel. SAE Technical Paper; 2000.

[85] Hyvönen J, Haraldsson G, Johansson B. Operating range in a multi cylinder HCCI engine using variable compression ratio. SAE Technical Paper; 2003.

[86] Sankaralingam RK, Venugopal T. Current trends on combustion control methods using fuel reactivities. International Journal of Automotive \& Mechanical Engineering. 2016;13.

[87] Nathan SS, Mallikarjuna J, Ramesh A. Effect of mixture preparation in a diesel HCCI engine using early in-cylinder injection during the suction stroke. International journal of automotive technology. 2007;8:543-53.

[88] Jun D, Iida N. A study of high combustion efficiency and low CO emission in a natural gas HCCI engine. SAE Technical Paper; 2004. 
[89] Rahman KA, Ramesh A. Effect of reducing the methane concentration on the combustion and performance of a biogas diesel predominantly premixed charge compression ignition engine. Fuel. 2017;206:117-32.

[90] Van Blarigan P. Advanced internal combustion engine research. DOE Hydrogen Program Review NREL/CP-570-28890. 2000:1-19.

[91] Kozarac D, Taritas I, Vuilleumier D, Saxena S, Dibble RW. Experimental and numerical analysis of the performance and exhaust gas emissions of a biogas $/ \mathrm{n}$ heptane fueled HCCI engine. Energy. 2016;115:180-93.

[92] Hairuddin AA, Yusaf T, Wandel AP. Single-zone zero-dimensional model study for diesel-fuelled homogeneous charge compression ignition (HCCI) engines using Cantera. International Journal of Automotive and Mechanical Engineering. 2016;13.

[93] Jun D, Ishii K, Iida N. Combustion analysis of natural gas in a four stroke HCCI engine using experiment and elementary reactions calculation. SAE Technical Paper; 2003.

[94] Maghbouli A, Saray RK, Shafee S, Ghafouri J. Numerical study of combustion and emission characteristics of dual-fuel engines using 3D-CFD models coupled with chemical kinetics. Fuel. 2013;106:98-105.

[95] Kong S-C, Marriott CD, Rutland CJ, Reitz RD. Experiments and CFD modeling of direct injection gasoline HCCI engine combustion. SAE Technical Paper; 2002.

[96] Wang X, Liu H, Zheng Z, Yao M. Development of a reduced nbutanol/biodiesel mechanism for a dual fuel engine. Fuel. 2015;157:87-96.

[97] Flowers DL, Aceves SM, Martinez-Frias J, Dibble RW. Prediction of carbon monoxide and hydrocarbon emissions in iso-octane HCCI engine combustion using multizone simulations. Proceedings of the Combustion Institute. 2002;29:687-94.

[98] Babajimopoulos A, Lavoie GA, Assanis DN. Modeling HCCI combustion with high levels of residual gas fraction-A comparison of two VVA strategies. SAE Technical paper; 2003.

[99] Liu J, Yang F, Wang H, Ouyang M. Numerical study of hydrogen addition to DME/CH4 dual fuel RCCI engine. International Journal of Hydrogen Energy. 2012;37:8688-97.

[100] Flowers D, Aceves S, Martinez-Frias J, Hessel R, Dibble R. Effect of mixing on hydrocarbon and carbon monoxide emissions prediction for isooctane HCCI engine combustion using a multi-zone detailed kinetics solver. SAE Technical Paper; 2003.

[101] Mosbach S, Kraft M, Bhave A, Mauss F, Mack JH, Dibble RW. Simulating a Homogeneous Charge Compression Ignition engine fuelled with a DEE/EtOH blend. SAE Technical Paper; 2006.

[102] Visakhamoorthy S, Tzanetakis T, Haggith D, Sobiesiak A, Wen JZ. Numerical study of a homogeneous charge compression ignition (HCCI) engine fueled with biogas. Applied Energy. 2012;92:437-46.

[103] Awate S, Jeeva B, Chowdhury A, Sreedhara S. Numerical Investigations of HCCI Combustion. work. 2013;13:16. 